\title{
Can the Small College Library Afford Rare Books?
}

Warren L. Perry is librarian at the College of Puget Sound, Tacoma, Washington.

T F WE accept the fact that rare books 1 involve us in the problems and expense of special preparation, special custody, and special use, can the small college library afford them? From the point of view of the administrator I would like to ask and perhaps answer certain inescapable questions involved in the possession of rare books.

We hold for our library the following as a goal: All books and periodicals, documents, serials or other materials shall be of such nature that their presence can be justified by their useful relation to our curriculum and our cultural purpose. Likewise all of our equipment, and all of our technical processes must be efficiently directed toward the interpretation and distribution of our resources to our patrons, either students or faculty, so that we may be a true service institution. We may miss our goal but we strive for it.

Should we then have rare books and give the careful and expensive custody due them? What rarities have a place in the small college library plan? How are we to obtain them?

We are being told today that the accumulative stage of library development is over and that we have entered on a phase of refining and sifting, with an emphasis on functioning materials and their distribution, and not mere numerical growth. This may be quite true of many institutions, but most of the small college libraries I know in this area, have not yet reached the stage where they may become more useful by growing smaller.

We can, however, profit by determining policies of growth here in the far west, developing wisely so that we need not later throw out books and other materials which have been expensive to acquire, process, and house, and which will also be expensive to discard. I know of only one librarian who is articulate on the question of cost accounting a discard program. $\mathrm{He}$ is convinced that it is cheaper to keep a book than to "uncatalog" it.

The libraries not now blessed or burdened with rare book accumulations, or perhaps with only a start on a small scale toward treasure rooms, should develop definite conceptions of the ultimate desirable content of their collections of rarities. If we have a Shaw list of rare books for the college library, I have not heard of it. I have seen many rare book collections and treasure rooms in various libraries. Were a survey to be made I am sure that there would prove to be almost no similarity or correlation among them.

This is a typical small college library here in the west: It has 30 to 50,000 volumes; a staff of $I$ to 3 trained librarians, perhaps I clerical assistant 
working half time, and Io to 15 student helpers, most of them under National Youth Administration appointment. A student body 400 to 600 in size and a faculty of about 50 are served. This library may be housed none too adequately in any of the following: an outgrown Carnegie building erected in 1907 ; temporary quarters in a classroom building; a remodeled dormitory, church, gymnasium, or powerhouse. I envy a few of my colleagues who operate in modern library buildings but most of them feel that their quarters are already too small. In addition such a library is comparatively young in years and supports a liberal arts curriculum.

\section{Two Types of Collections}

College libraries are apt to find themselves blessed and burdened with two types of collections, rather loosely called "rare book collections:"

I. Special collections from the subject angle. They may without doubt contain rarities if at all extensive. Special collections are of questionable value to the small college library. Seldom is the curriculum detailed enough to make the possession of a special collection very useful.

2. Memorial collections. Again these may contain rarities, but the memorial feature comes first. Here again we must qualify. No one doubts the value of the Widener memorial at Harvard. Still I have heard rumors that the strategic place in the building which it occupies might better be used for more essential library purposes.

The memorial collection is often a white elephant and inclines to be a frozen asset of books, which is not kept alive and growing because of its memorial character.

I can approach this problem with an

DECEMBER, 1939 open mind. I have no rare book collection now to care for and administer, or to justify. It would be wise for my library and any other similarly situated institution to evolve a rare book policy in advance of rare book ownership. We never know when the moment will come and some lavish gift will precipitate us into the pleasures and trials of rare book custody.

I have no wish to discount the cultural stimulation of rare books, or to speak against their presence in college libraries, however small. The small institution, none too well supported by funds, staff and equipment, should not, however, unthinkingly undertake the custody of any and all printed materials, rare or otherwise.

Libraries connected with educational institutions range from the simple elementary school library, to the university library, complex and all-inclusive. Somewhere in between lies the college library. It must partake of the qualities of both extremes. The college librarian must determine his limits and boundaries, aided intelligently by some of his faculty and hampered exceedingly by the indifference or perhaps blind zeal of others. Here stated and accepted policies are helpful. For example, one college library has an established policy against acquisition by gift or purchase of any books, rare or otherwise, in languages not taught in the college.

\section{Definitions of Rare Books}

At this point perhaps I should define a rare book. A few months ago I solicited definitions from a number of my colleagues. They contained the following, among others:

I. All books costing over $\$ 25$. Is it not 
a mistake to regard Bossert, Das Ornamentwerk as rare and lock it up somewhere? Its greatest use lies in the studio of the art department, and I know of libraries that have cheerfully cut it up into separate pages so that more students could use it at once. It costs us \$29.75; a lost investment if we lock it up, and regard is as a rarity. It is in print and readily replaceable.

2. All books from a certain donor. Another rather superficial definition of a rare book, though it no doubt pleases the donor. This definition comes from a library which apparently has a memorial masquerading as a rare book collection.

3. All books by certain authors, admittedly without reference to actual rarity. This indicates to me a special subject collection hampered as to use by the "rare" designation if it involves the type of custody deserved by actual rarities.

4. Arbitrary date designations, equally unsatisfactory.

I would seem to be eliminating the possibility of rare books entirely. We need to be sure that we are using our own definitions of rarity and have not taken over the private collector's point of view. We have done so, I think, if we find ourselves taking care of:

First editions for the sake only of their primary state

Fine printing and binding as art objects

Books of great age for their age alone

Special collections of books on subjects not related to the fields of the curriculum

(Apropos of the last, an eastern liberal arts college library has recently issued a short-title catalog running to 13 I pages, listing its special collection on dogs. How much more useful would have been a library handbook! If the college has one, I have not seen it.)

\section{Relics and museum items}

(A western institution of 70,000 volumes announced in its last annual report the acquisition of the following: "Two revolvers and a pearl gold-hilted sword ... taken from
Confederate prisoners; a cane belonging to President Franklin Pierce; and four volumes covering the business transactions from I816-1827 of the Madeira branch of a New York exporting firm.")

\section{Suggested Content of Rare Book Collec- tions}

If we are to have rare book collections, and Mr. Powell ${ }^{1}$ tells us how they are to be useful and helpful, and hence justified, what should be their content?

I. A bibliographical museum, selected to show by samples, history of books, printing, illustration, and binding. It need not be large or costly. I am told that such a collection of about 300 volumes could be brought together for less than $\$ 5,000$.

2. Memorabilia of the institution, a definite obligation not to be neglected. Such a collection should contain: (I) college publications, (2) material about the college, (3) books by members of the faculty, students, alumni, etc.

3. Books really scarce and hard to find, which we all must have and use in the college field. They are not necessarily expensive but seldom on the market; for example:

Masson's Life of Milton. One New York firm has seven standing orders unfilled.

Essays in Critical Realism. I922. I have seen one quotation in twelve years.

Bent's early volumes on Life Histories of American Birds, issued by the U.S. National Museum, available free on request less than twenty years ago but now exceedingly scarce.

Ridgway's Color Standards and Color Nomenclature.

If we have such titles we must protect them. They will not grow commoner, nor are they likely to be reprinted.

4. Significant and useful reference material, perhaps in manuscript, about our own regions and their resources as contrasted with local history of the genealogical and pioneer narrative type, interesting to have

'See "The Function of Rare Books" in this issue pp. $97-103$. 
but not of primary usefulness in a liberal arts college library.

Most rare book collections do not function because they have accumulated without plan as a result of gifts. Is a book ever really free? Are we honest if we accept and house gifts that cannot function in our curriculum, which are costly to catalog and to maintain? We give all too little attention to the cost of accepting and keeping gifts.

I come to the same conclusions whenever I take up a library question. We will really be money ahead in the long run if we cold-bloodedly buy our rare book collections on a well-worked-out plan, to provide us with the unusual book materials we need to use. It will perhaps be many weary years before we get a balanced useful collection together from gifts, and many civil war swords and first editions will be accumulated in the meantime.

I hope that the small college library can remain a functioning unit pared down to material, use of which justifies its presence, leaving the activities of the museum, the archives, and the all-inclusive research library to the institutions whose programs justify the attendant expense. 